\title{
Uluslararası Muhasebe Eğitimi Standartları Kapsamında Muhasebe Eğitiminin Türkiye'deki Akademisyenler ve Muhasebe Meslek Mensupları Açısından İncelenmesi ${ }^{1}$
}

\author{
Büşra TOSUNOĞLU*, Selim CENGİZ**, Zafer ANADOLU***
}

ÖZ

$\mathrm{Bu}$ çalışmanın amacı, uluslararası muhasebe eğitimi standartları kapsamında muhasebe eğitiminin akademisyenler ve muhasebe meslek mensupları açısından incelenmesini içermektedir. Bu doğrultuda üç hipotez oluşturulmuş ve Trabzon İl'inde faaliyet gösteren muhasebe meslek mensuplarına ve Türkiye'de muhasebe eğitimi veren akademisyenlere bir anket uygulanmıştır. Oluşturulan hipotezlerin test edilmesinde bağımsız örneklem $t$ testi kullanılmıştır. Analiz bulgularına göre; akademisyenlerin ve muhasebe meslek mensuplarının muhasebe eğitimiyle ilgili farklı düşüncelere sahip olduğu söylenebilmektedir. Akademisyenlere göre muhasebe eğitiminde bilgi önemliyken muhasebe meslek mensuplarına göre ise yetenek ve tutumun önemi daha yüksektir.

Anahtar Kelimeler: Uluslararası Muhasebe Eğitimi Standartları, Muhasebe Eğitimi, Akademisyenler ve Muhasebe Meslek Mensupları

JEL Sinıflandırması: M40, M41, M42

\section{Examination of Accounting Education within the scope of International Accounting Education Standards in terms of Academics and Professional Accountants in Turkey}

\begin{abstract}
The purpose of this study is to examine the accounting education in terms of academicians and professional accountants within the framework of international accounting education standards. In this regard, 3 hypotheses were constituted and a questionnaire was conducted to the accounting professions who are operating in Trabzon province and academicians who are providing training for accounting. Independent sample $t$ test was used to test the hypotheses. According to findings of the analysis, it may be seen that, academicians and accounting professions have different thoughts about accounting education. According to the academicians, knowledge is important in accounting education, but according to accounting profession, skill and attitude are more important.
\end{abstract}

Keywords: International Accounting Education Standards, Accounting Education, Academicians and Accounting Professions

JEL Classification: M40, M41, M42

Geliş Tarihi / Received: 02.01.2018 Kabul Tarihi / Accepted: 30.05.2018

\footnotetext{
${ }^{1}$ Bu makale, 21-23 Eylül tarihlerinde Uşak’ta yapılan Uluslararası Uygulamalı Sosyal Bilimler Kongresi’nde bildiri olarak sunulmuştur.

* Dr. Öğr. Üyesi, Gümüşhane Üniversitesi, İ̈BF, İşletme Bölümü, busra.tosunoglu@gumushane.edu.tr, ORCID: 0000-0001-6292-2770

** Dr. Öğr. Üyesi Çankırı Karatekin Üniversitesi, İ̈BF, Bankacılık ve Finans Bölümü, selimcengiz71@ @otmail.com, ORCID: 0000-0002-2013-9590

**** Serbest Muhasebeci Mali Müşavir, zaferanadolu@msn.com, ORCID: 000-0002-1705-4510
} 


\section{GİRIŞ}

Bilim, ekonomi ve teknolojide meydana gelen hızlı değişim beraberinde eğitim sisteminin gelişimini de getirmektedir. Söz konusu bu değişimden etkilenen alanlardan birisi de şüphesiz muhasebedir (Çelik ve Ecer, 2009: 617). Önceki yıllarda işletmeler kurumsal bir yapıya sahip olmadıkları için muhasebe işlemleri profesyonel kişiler yerine işletme sahipleri tarafindan yürütülmekte günümüzde ise işletmelerin faaliyet alanlarını genişletmeleri başarılı bir yönetim anlayışını benimsemelerini zorunlu kılmıştır. Çoğu işletme artık muhasebe sistemlerini daha profesyonel oluşturmaya başlamış ve bu alanda uzman kişileri çalışma ekiplerine dâhil etmiştir (Çürük ve Doğan, 2002: 108).

Hemen hemen bütün büyük şirketlerde muhasebe bilgileri titizlikle kaydedilme, raporlanma ve yorumlanma eğilimindedir (Wilkin ve Collier, 2009: 49). Bu eğilim işletmelerin ilgili kişilere karşı hesap verilebilirlik ihtiyacından doğmaktadır. Muhasebe meslek mensuplarından sadece yatırımcılara ve kredi kuruluşlarına değil aynı zamanda diğer bilgi kullanıcılarına da hizmet etmeleri beklenmektedir. Bu nedenle söz konusu meslek mensuplarının ihtiyaçlara cevap verebilmeleri için gelişimleri yakından takip etmeleri ve geniş bir bakış açısına sahip olmalar1 gerekmektedir (IFAC, 2003: 28).

Yukarıda genel olarak bahsedilen önemden hareketle muhasebe ve finans alanında bir takım düzenlemelerin yapıldığı görülmektedir (Montano vd., 2010: 345-346). Ayrıca muhasebe eğitiminde de uluslararası düzeyde standartların oluşturulmasına karar verilmiştir. Uluslararası Muhasebeciler Federasyonu (IFAC: International Federation of Accountants) tarafindan Uluslararası Muhasebe Eğitim Standartları Kurulu (IAESB: International Accounting Education Standart Board) oluşturulmuştur (www.ifac.org, E.T. 15.08.2017). Bu kurul muhasebe mesleğinde mesleki bilgi, beceri ve tutum hakkında standartları oluşturmasının yanı sıra çeşitli yayın ve dokümanlarla da muhasebe eğitimine yön vermiştir (www.iaesb.org, E.T. 15.08.2017). 2005 yılında yayınlanan ve 2014 yılında revize edilen standartların ilk dördü meslek mensuplarının eğitimleri ile ilgili, diğer üç standart eğitim sonrası için son standart ise denetim ile ilgili hazırlanmıştır. Oluşturulan standartlar ilişkin bilgiler Tablo 1'de belirtilmektedir.

Tablo 1: Uluslararası Muhasebe Eğitimi Standartları

\begin{tabular}{|l|l|}
\hline \multicolumn{1}{|c|}{ Standart } & \multicolumn{1}{c|}{ Açıklama } \\
\hline $\begin{array}{l}\text { IES 1: Profesyonel Muhasebe Eğitim } \\
\text { Programlarına Giriş Koşulları }\end{array}$ & $\begin{array}{l}\text { Bu standart, Profesyonel muhasebe eğitimi programlarına giriş } \\
\text { için gerekli eğitimleri içermektedir. }\end{array}$ \\
\hline IES 2: İlk Mesleki Gelişim - Teknik Yeterlilik & $\begin{array}{l}\text { Bu standart, profesyonel muhasebecilik mesleğine yönelik } \\
\text { dersleri içermektedir. }\end{array}$ \\
\hline IES 3: İlk Mesleki Gelişim - Teknik Yeterlilik & $\begin{array}{l}\text { Bu standart, profesyonel muhasebe mesleği için gerekli olan } \\
\text { mesleki becerileri (entelektüel, teknik, kişisel, kişilerarası ve } \\
\text { örgütsel) açılamaktadır. }\end{array}$ \\
\hline $\begin{array}{l}\text { IES 4: İlk Profesyonel Gelişim - Profesyonel } \\
\text { Değerler, Etik ve Tutumlar }\end{array}$ & $\begin{array}{l}\text { Bu standart, profesyonel muhasebe mesleğine yönelik } \\
\text { uygulanması gereken, etik değerleri ve davranışları } \\
\text { açklamaktadır. }\end{array}$ \\
\hline $\begin{array}{l}\text { IES 5: IIlk Profesyonel Gelişim - Pratik } \\
\text { Deneyim }\end{array}$ & $\begin{array}{l}\text { Bu standart, profesyonel muhasebecilerin alması pratik deneyim } \\
\text { kazanmalarına yönelik bilgileri içermektedir. }\end{array}$ \\
\hline $\begin{array}{l}\text { IES 6: Başlangıç Mesleki Gelişimi - Mesleki } \\
\text { Yeterliliğin Değerlendirilmesi }\end{array}$ & $\begin{array}{l}\text { Bu standart, adayların mesleki yeterlilik ve yetkinliklerinin } \\
\text { değerlendirilmesini içermektedir. }\end{array}$ \\
\hline IES 7: Sürekli Mesleki Gelişim & $\begin{array}{l}\text { Bu standart, uzman muhasebecilerin yetkinliklerinin sürekli } \\
\text { iyileştirilmesinin önemini ve yaşam boyu öğrenme konusundaki } \\
\text { kararlılı̆̆ını teşvik edici bilgileri içermektedir. }\end{array}$ \\
\hline $\begin{array}{l}\text { IES 8: Finansal Tabloların Denetimlerinden } \\
\text { Sorumlu Ortaklar İçin Mesleki Yeterlilik }\end{array}$ & $\begin{array}{l}\text { Bundart, belirli çevre ve endüstrilerde çalışanların da } \\
\text { aralarında bulunduğu denetim uzmanları için olması gereken } \\
\text { yetenekleri içermektedir. }\end{array}$ \\
\hline
\end{tabular}

Kaynak: (The International Accounting Education Standards Board, 2017, www.iaesb.org) 
Muhasebe eğitimine yönelik ilgili literatür incelendiğinde pek çok çalışmanın varlığından bahsetmek mümkündür. Söz konusu çalışmalara kapsamlı bir şekilde literatür araştırması kısmında değinilmiştir. İlgili literatür incelendiğinde genel olarak muhasebe eğitiminin değerlendirmesi ön lisans, lisans ve lisansüstü eğitim alan öğrencilere yönelik yapılmakta, akademisyen ve meslek mensuplarının görüşlerine yönelik değerlendirmelerin yapıldığı çalışmaların eksikliği literatürde bir boşluk olarak görülmektedir. $\mathrm{Bu}$ durumdan hareketle bu çalışmanın amacı muhasebe eğitiminin akademisyen ve meslek mensuplarının görüşleri doğrultusundan değerlendirilmesini içermektedir.

Çalışmada bir bütünlük oluşturabilmek için ilk olarak kavramsal çerçeve hazırlanmış ardından ilgili literatüre yer verilmiştir. Daha sonra ise araştırmanın uygulama kısmında elde edilen bulgular açıklanmıştır.

\section{LITERATÜR ARAŞTIRMASI}

Gerek uluslararası gerekse ulusal literatür incelendiğinde muhasebe eğitimine yönelik pek çok çalışmanın varlığından bahsetmek mümkündür. Söz konusu çalışmalar uluslararası ve ulusal çalışmalar olarak iki kısma ayrılmıştır. Uluslararası literatüre ilişkin değerlendirmeler tablo 2'de ulusal literatüre ilişkin değerlendirmeler ise tablo 3 'te belirtilmektedir.

Tablo 2: Muhasebe Eğitimine Yönelik Uluslararası Literatür

\begin{tabular}{|c|c|}
\hline Yazarlar/Çalışma Yılı & Açıklama \\
\hline Saville (2007) & $\begin{array}{l}\text { Profesyonel muhasebe eğitiminin temel amacinın topluma yarar sağlayacak } \\
\text { muhasebeci yetiştirme olması gerektiğini belirtmişlerdir. Bu nedenle muhasebe } \\
\text { eğitiminde uluslararası muhasebe eğitim standartlarının dikkate alınması gerektiği } \\
\text { ifade edilmiştir. }\end{array}$ \\
\hline Eastman ve Hazera (2009) & $\begin{array}{l}\text { Muhasebe eğitiminin ülkeler arası farklılık gösterdiği belirtilmiştir. Bu farklılıktan } \\
\text { hareketle muhasebe eğitiminde bir standardın oluşturulması gerekliliği çalışmada } \\
\text { ifade edilmiştir. }\end{array}$ \\
\hline Moehrle vd. (2009) & $\begin{array}{l}\text { Üniversitelerde verilen muhasebe derslerinin müfredatlarında standartları dikkate } \\
\text { alarak birtakım değişikliklerin yapılması gerekliliğini ifade etmişlerdir. }\end{array}$ \\
\hline Sugahara vd. (2010) & $\begin{array}{l}\text { Üniversitelerde verilen muhasebe eğitimlerinde bilginin yanı sıra yetenek ve tutuma } \\
\text { da ağırlı verilmesi gerekliliği ifade edilmiştir. }\end{array}$ \\
\hline Stivers vd. (2011) & $\begin{array}{l}\text { Akademisyenlere yönelik yapılan çalışmada özellikle genel muhasebe dersinde } \\
\text { öğrencilerin farkındalık kazanmalarına yönelik eğitimlere yer verilmesi gerektiği } \\
\text { ifade edilmiştir. }\end{array}$ \\
\hline Crawford vd. (2011) & $\begin{array}{l}\text { Uluslararası Muhasebe Eğitimi Standartlarının meslek mensuplarının görüşleri } \\
\text { doğrultusunda değerlendirildiği çalışmada söz konusu standartların uygulanabilirliği } \\
\text { noktasında birtakım sıkıntıların olduğu belirtilmiştir. }\end{array}$ \\
\hline Watty (2005) & $\begin{array}{l}\text { Avusturalya, Japonya ve Sri Lanka'daki akademisyenlerin uluslararası muhasebe } \\
\text { eğitimi standartlarına yönelik değerlendirmeleri incelenmiştir. }\end{array}$ \\
\hline Kostadinovski vd. (2013) & $\begin{array}{l}\text { Uluslararası muhasebe eğitimi standartlarının muhasebe eğitiminin geliştirilmesi ve } \\
\text { muhasebe mesleğinin güçlendirilmesine yönelik katkı sağladığı belirtilmektedir. }\end{array}$ \\
\hline Frijat ve Shbeilat (2016) & $\begin{array}{l}\text { Ürdün üniversitelerindeki akademisyenlerin görüşleri doğrultusunda IES2 ile uyumlu } \\
\text { olarak muhasebe öğrenme çıktıları için teknik yeterliliğin geliştirilmesine yönelik } \\
\text { eğilimdeki rolü tespit edilmiştir. Çalışmada Ürdün üniversiteleri arasında üniversite } \\
\text { yeterlik testi sonuçlarındaki eşitsizliği azaltmak için ön koşul olarak muhasebe eğitim } \\
\text { planlarının standartlaştırılmasına yönelik olarak çalışmasını gerektiren bir dizi } \\
\text { öneriler bulunmaktadır. }\end{array}$ \\
\hline
\end{tabular}


Tablo 3: Muhasebe Eğitimine Yönelik Ulusal Literatür

\begin{tabular}{|c|c|}
\hline Yazarlar/Çalışma Yılı & Açıklama \\
\hline Çürük ve Doğan (2002) & $\begin{array}{l}\text { İ̧̧letmelerin talepleri doğrultusunda muhasebe müfredatlarının içeriğini incelendiği } \\
\text { çalışmada teorik bilgiden çok uygulamaya yönelik eğitimlerin verilmesi, örnek olay } \\
\text { çalışmaları veya uygulamalı programlar ile desteklenmesi, lisansüstü tezlerin } \\
\text { genellikle işletmelerin karşılaştıkları problemleri çözecek nitelikte hazırlanması } \\
\text { gerektiği ifade edilmektedir. }\end{array}$ \\
\hline Zaif ve Ayanoğlu (2007) & $\begin{array}{l}\text { Türkiye'deki üniversitelerde verilen muhasebe eğitimlerinde belirli bir standardın } \\
\text { olmamasının muhasebe eğitimi kalitesini etkilediği ifade edilmektedir. }\end{array}$ \\
\hline Uyar (2008) & $\begin{array}{l}\text { Uluslararası muhasebe standartları çerçevesinde Türkiye'deki muhasebe eğitimin } \\
\text { incelendiği çalışmaya göre bilgi teknolojileri konusunda derslerin yetersiz olduğu } \\
\text { tespit edilmiştir. }\end{array}$ \\
\hline Çubukçu (2012) & $\begin{array}{l}\text { Muhasebe mesleğine olan güveninin arttırılabilmesinin meslek mensuplarının etik } \\
\text { değere sahip olmalarıla mümkün olacağı ifade edilmektedir. Bu nedenle meslek } \\
\text { mensubu öğrencilere yönelik etik eğitiminin başlamasının gerektiği belirtilirken } \\
\text { üniversitelerin lisans ve lisansüstü programlarında etik derslerinin henüz yeterli } \\
\text { düzeyde olmadığı tespit edilmiştir. }\end{array}$ \\
\hline Kutluk vd. (2012) & $\begin{array}{l}\text { Türkiye'de faaliyet gösteren muhasebe meslek mensuplarının muhasebe eğitimine } \\
\text { yönelik düşüncelerini içeren çalı̧̧mada üniversitede muhasebe eğitim alan } \\
\text { öğrencilerin beklentileri karşılayacak derece etkin muhasebe eğitimi almadıkları } \\
\text { belirtilmektedir. }\end{array}$ \\
\hline Öztürk ve Fındık (2016) & $\begin{array}{l}\text { Türkiye'deki muhasebe eğitiminin standartlara uyum noktasında yaşadığı sıkıntıların } \\
\text { incelendiği çalışmada muhasebenin değerlerinden profesyonellik, tekdüzelik ve } \\
\text { şeffaflık eğiliminin yoğun olduğu tespit edilmiştir. }\end{array}$ \\
\hline Can ve Demirci (2016) & $\begin{array}{l}\text { Uluslararas1 muhasebe eğitimi standartlarından IES2'nin Türkiye'deki muhasebe } \\
\text { eğitiminde uygulanabilirliğinin incelendiği bu çalışmaya göre muhasebe müfredatına } \\
\text { göre en uygun bölümün İşletme Bölümü olduğu tespit edilmiştir. }\end{array}$ \\
\hline Gökten ve Gökten (2016) & $\begin{array}{l}\text { Uluslararası muhasebe eğitimi standartlarının Türkiye'de uygulanabilirliğinin } \\
\text { incelendiği çalışmada bu standartlardan ilk beş tanesinin geçerli olduğu, IES2 ve } \\
\text { IES6'nın kısmen geçerli olduğu IES3'ün ise geçerli olmadığ1 tespit edilmiştir. }\end{array}$ \\
\hline
\end{tabular}

Muhasebe eğitimine yönelik literatür değerlendirildiğinde muhasebe müfredatlarının oluşturulması sürecinde akademisyenlerin uygulayıcıların (muhasebe meslek mensupları) görüşlerinin farklılaştığı görülmektedir. Akademisyenlerin genellikle ders kitaplarını ve araştırmaları dikkate alarak oluşturdukları muhasebe müfredatları uygulayıcılar (muhasebe meslek mensupları) tarafından eleştirilmektedir. Muhasebe meslek mensuplarına göre üniversitelerdeki muhasebe müfredatları işletmelerin, ihtiyaç duyduğu yetenek ve uygulama açısından eksik kalmakta ve bu durum üniversite öğrencilerin iş yaşamlarında ciddi sıkıntı yaşamalarına sebebiyet vermektedir.

Muhasebe meslek mensuplarının iş yaşamlarının kaliteli olması, almış oldukları muhasebe eğitimiyle paralellik göstermektedir. Bu nedenle muhasebe eğitiminde olması gereken kriterlerin belirlendiği ve bu kriterlerin belirli bir standart şeklinde sunulduğu bilinmektedir. Uluslararası muhasebe eğitimi standartları doğrultusunda oluşturulan kriterler ve bu kriterlere ilişkin alt kriterler tablo 4' te belirtilmiştir. 
Tablo 4: Uluslararası Muhasebe Eğitimi Standartları Çerçevesinde Oluşturulan Standartlar

\begin{tabular}{|c|c|c|}
\hline Standartlar & Kriterler & Alt Kriterler \\
\hline $\begin{array}{l}\text { IES 1: Profesyonel Muhasebe Eğitim Programlarına Giriş } \\
\text { Koşulları } \\
\text { IES 2: İlk Mesleki Gelişim - Teknik Yeterlilik } \\
\text { IES 3: İlk Mesleki Gelişim - Teknik Yeterlilik } \\
\text { IES 4: İlk Profesyonel Gelişim - Profesyonel Değerler, Etik ve } \\
\text { Tutumlar }\end{array}$ & Bilgi & $\begin{array}{l}\text {-Muhasebe, Finans ve ilişkili diğer } \\
\text { bilimler } \\
\text {-İsletme Aktiviteleri ve Yönetimi } \\
\text {-Bilgi Teknolojisi }\end{array}$ \\
\hline $\begin{array}{l}\text { IES 5: İlk Profesyonel Gelişim - Pratik Deneyim } \\
\text { IES 6: Başlangıç Mesleki Gelişimi - Mesleki Yeterliliğin } \\
\text { Değerlendirilmesi }\end{array}$ & Yetenek & $\begin{array}{l}\text {-Entelektüel Yetenek } \\
\text {-Teknik ve İşlevsel Yetenek } \\
\text {-Kişisel Yetenek } \\
\text {-Kişilerarası İletişim Yetenekleri } \\
\text {-Organizasyonel ve İşletme Yönetimi } \\
\text { Yeteneği }\end{array}$ \\
\hline IES 7: Sürekli Mesleki Gelişim & Tutum & $\begin{array}{l}\text {-Genel İlkeler } \\
\text {-Ayrintılı İlkeler }\end{array}$ \\
\hline
\end{tabular}

Kaynak: (Pratama, 2015, The International Accounting Education Standards Board, 2017, www.iaesb.org)

Tablo 4'te belirtilen bilgi (a), yetenek (b) ve tutum (c) kriterleri değerlendirildiğinde; a) İşletmeler için finansal raporlama, vergilendirme, iş etiği ve organizasyonel bilginin öneminden hareketle üniversitelerde verilen muhasebe müfredatlarında söz konusu konulara ağırlık verilmesi gerekmektedir. b) Bir kişiden yazılı ve elektronik ortamlardan bilgi toplayabilme, meydana gelen problemleri çözebilme, raporlama yeteneği elde edebilme, takım halinde çalışabilme kabiliyetine sahip olabilme ve farklı kültür ve dillerde etkili yazma ve dinleme becerisi kazanabilme, bireylerin iş hayatlarında başarılı olabilmelerini sağlamaktadır. c) Kamu yararı ve sosyal sorumluluk duyarlılığına sahip olabilme, güvenilir sorumlu, yasa ve yönetmeliklere uygun hareket edebilme, iş aktivitelerinde etik ve iyi yönetim davranış1 edinebilme davranışına yönelik eğitimlerin de muhasebe müfredatlarında yer alması gerekmektedir.

\section{ARAŞTIRMANIN AMACI, METODOLOJISİ VE BULGULARI}

\subsection{Araştırmanın Amacı}

$\mathrm{Bu}$ çalışmanın amacı, uluslararası muhasebe eğitimi standartları çerçevesinde muhasebe eğitiminin akademisyen ve muhasebe meslek mensupları açısından değerlendirmektir. Araştırmada muhasebe eğitiminde bilgi, yetenek ve tutum boyutları dikkate alınmıştır.

\subsection{Araștırmanın Metodolojisi}

\subsection{1. Örnekleme Süreci}

Araştırmanın evreni Türkiye'deki üniversitelerde muhasebe alanında eğitim veren akademisyenler ve faaliyet gösteren muhasebe meslek mensuplarından oluşmaktadır. Örneklem kütlesinin belirlenmesinde evreni oluşturan her öğenin örneğe girme şansının eşit olduğu basit tesadüfi örnekleme yöntemi kullanılmıştır (Arıkan, 2004: 141). Elde edilen verilerin normal dağılıma uygunluğunun tespit edilmesinde normallik testi yapılmıştır. İstatistiksel analizlerde parametrik testlerin kullanılabilmesi için verilerin normal dağılıma uygun olması gerekmektedir. Tabachnick ve Fidell (2013)'e göre çarpıklık ve basıklık değerlerinin $+1,5$ ve $-1,5$ değerleri arasında olduğu durumlarda dağılımın normal dağılım gösterdiği kabul edilmektedir. Çalışmada dikkate alınan bilgi, yetenek ve tutum kriterlerinin ilişkin çarpıklık ve basıklık değerlerine 
bakıldığında; bilgi ölçeğinin çarpıklık- basıklık değerlerinin (-,809 ve ,209), yetenek ölçeğinin çarpıklık- basıklık değerlerinin $(-1,452$ ve, 208$)$ ve tutum ölçeğinin çarpıklık ve basıklık değerlerinin $(-1,457$ ve ,208) arasında olduğu ve bu değerlerin normal dağılım gösterdiği belirtilebilmektedir.

Araştırmada Türkiye'de faaliyet gösteren akademisyen ve muhasebe meslek mensuplarına anket uygulanmış, hatalı ve eksik olan anketler çıkarılarak 157 anket dikkate alınmıştır. Anketin güvenilirliği Cronbach Alfa katsayısıyla ölçülmüştür. Analiz sonucu her bir faktöre ilişkin Cronbach Alfa değerleri Tablo 5'te belirtilmektedir.

Tablo 5: Ölçeğin İç Tutarlılık Analizi Sonuçları

\begin{tabular}{|c|c|c|}
\hline Ölçekler & Değişken Sayısı & Cronbach's Alpha ( $\boldsymbol{\alpha})$ \\
\hline Bilgi & 20 & 0,978 \\
\hline Yetenek & 25 & 0,989 \\
\hline Tutum & 8 & 0,986 \\
\hline
\end{tabular}

Araştırma kapsamında hazırlanan anket toplam 157 akademisyen ve muhasebe meslek mensubu tarafından cevaplandırılmış olup, araştırmaya katılan deneklerin demografik özellikleri Tablo 6'da sunulmuştur.

Tablo 6: Araştırmaya Katılan Kişilerin Demografik Özellikleri İtibariyle Dağılımı

\begin{tabular}{|c|c|c|}
\hline & Frekans & Yüzde (\%) \\
\hline \multicolumn{3}{|l|}{ Cinsiyet } \\
\hline Kadın & 88 & 56,1 \\
\hline Erkek & 69 & 43,9 \\
\hline \multicolumn{3}{|l|}{ Yaş } \\
\hline $25-30$ & 55 & 35,0 \\
\hline $31-35$ & 45 & 28,7 \\
\hline $36-40$ & 23 & 14,6 \\
\hline $41-45$ & 21 & 13,4 \\
\hline 45 ve üstü & 13 & 8,3 \\
\hline \multicolumn{3}{|l|}{ Ĕ̈itim Durumu } \\
\hline Lisans & 83 & 52,9 \\
\hline Yüksek Lisans & 48 & 30,6 \\
\hline Doktora & 26 & 16,6 \\
\hline \multicolumn{3}{|l|}{ Meslekte Çalışma Süresi } \\
\hline $1-5$ y1l & 57 & 36,3 \\
\hline 6-10 y1l & 37 & 23,6 \\
\hline $11-15 \mathrm{y} 11$ & 29 & 18,5 \\
\hline $16-20$ y1l & 24 & 15,3 \\
\hline 21 ve üstü & 10 & 6,4 \\
\hline \multicolumn{3}{|l|}{ Meslek } \\
\hline Akademisyen & 68 & 43,3 \\
\hline Muhasebe Meslek Mensubu & 89 & 56,7 \\
\hline Toplam & 157 & 100,00 \\
\hline
\end{tabular}


Araştırmaya katılan kişilerin demografik özellikleri değerlendirildiğinde, katılımcıların büyük çoğunluğunun kadınlardan oluştuğu (\%56,1), ağırlıklı olarak 25-30 yaş aralığında olduğu $(\% 35,0)$ görülmektedir. Ayrıca eğitim durumuna göre bir değerlendirme yapıldığında, ağırlıklı olarak lisans ve lisansüstü eğitim alan katılımcı sayılarının birbirine yakın olduğu (\%52,9 ve \%47,2) ve katılımcıların büyük çoğunluğunun 1-5 yıl aralığında mesleki tecrübeye sahip oldukları $(\% 36,3)$ görülmektedir.

\subsubsection{Veri Toplama Yöntem ve Aracı}

Araştırmada anket yöntemi kullanılmıştır. Anket formu yüz yüze görüşme, telefon ve eposta ile yapılmıştır. Anket formu iki bölümden oluşmakta ve ilk bölümünde yer alan sorular, katılımcıların demografik özelliklerini belirlemeye yöneliktir. İkinci kısım ise muhasebe eğitiminin değerlendirilmesine yönelik sorulardan oluşmaktadır. Anket 5'li Likert ölçeğine (1: Hiç Önemli Değil, 2: Önemsiz, 3: Kararsızım, 4: Önemli ve 5: Çok Önemli) göre oluşturulmuş ve katılımcılardan sorulan her bir ifadeye kendi durumlarına uygun cevapları vermeleri istenmiştir. Araştırmada kullanılan anket soruları için uluslararası muhasebe eğitimi standartları çerçevesinde oluşturulan Pratama (2015)'nın çalışmasından yararlanılmıştır.

\subsubsection{Araştırmanın Değişkenleri ve Oluşturulan Hipotezler}

Uluslararası muhasebe eğitimi çerçevesinde akademisyen ve muhasebe meslek mensuplarının görüşlerinin değerlendirilmesine yönelik oluşturulan hipotezler aşağıdaki gibidir;

H1: Muhasebe eğitiminde bilginin önemi açısından akademisyen ve muhasebe meslek mensuplarının görüşleri arasinda fark vardır

H2: Muhasebe ĕgitiminde yeteneğin önemi açısından akademisyen ve muhasebe meslek mensuplarının görüşleri arasinda fark vardır.

H3: Muhasebe eğitiminde tutumun önemi açısından akademisyen ve muhasebe meslek mensuplarının görüşleri arasında fark vardır.

\subsection{Araştırmanın Bulguları}

Bu bölümde ilk olarak uluslararası muhasebe eğitimi standartları çerçevesinde belirlenen bilgi, yetenek ve tutum boyutlarının muhasebe eğitimindeki önemlerine ilişkin akademisyen ve muhasebe meslek mensuplarının görüşlerinde fark olup olmadığını tespit etmek için bağımsız örneklem t testi yapılmıştır. Daha sonra ise her bir kriterin alt boyutlarının öneminin karşılaştırılması için t testi tablolarına yer verilecektir.

\subsubsection{Muhasebe Eğitiminde Bilgi, Beceri ve Tutum Boyutlarının Önem Düzeylerinin Meslek Değişkenine İlişsin Bulguları}

Akademisyenler ile muhasebe meslek mensuplarının muhasebe eğitiminde bilgi, yetenek ve tutumun önemine ilişkin görüşlerinde fark olup olmadığı Tablo 7'de yer almaktadır. 
Tablo 7: Meslek Değişkenine Göre Bilgi, Yetenek ve Tutum Boyutlarının Önem Düzeylerinde Anlamı Bir Farkın Olup Olmadığını Belirlemek İçin Yapılan Bağımsız Grup T Testi Sonuçları

\begin{tabular}{|c|c|c|c|c|c|c|}
\hline Boyut & Grup & $N$ & $X$ & $S S$ & $F$ & $\boldsymbol{P}$ \\
\hline \multirow{2}{*}{$\overline{B i l g i}$} & Akademisyen & 68 & 3,721 & 1,039 & \multirow[t]{2}{*}{0,005} & \multirow[t]{2}{*}{, $015^{*}$} \\
\hline & Muhasebe Meslek Mensubu & 89 & 3,329 & 0,922 & & \\
\hline \multirow[t]{2}{*}{ Yetenek } & Akademisyen & 68 & 3,060 & 1,255 & \multirow[t]{2}{*}{12,258} & \multirow[t]{2}{*}{, $010^{*}$} \\
\hline & Muhasebe Meslek Mensubu & 89 & 3,751 & 1,073 & & \\
\hline \multirow[t]{2}{*}{ Tutum } & Akademisyen & 68 & 3,049 & 1,523 & \multirow[t]{2}{*}{27,783} & \multirow[t]{2}{*}{, $007 *$} \\
\hline & Muhasebe Meslek Mensubu & 89 & 3,915 & 1,141 & & \\
\hline
\end{tabular}

$* \mathbf{p}<0,05$

Yukarıdaki tablo incelendiğinde muhasebe eğitiminde bilgi, yetenek ve tutum boyutlarının önemine ilişkin akademisyen ve muhasebe meslek mensupları görüşlerinin farklı olduğu tespit edilmiştir $(p<0,05)$. Akademisyenler için muhasebe eğitiminde bilginin önemi yüksek iken muhasebe meslek mensuplarına göre ise tutum ve yeteneğin daha önemli olduğu söylenebilmektedir. Bu doğrultuda;

H1: Muhasebe eğitiminde bilginin önemi açısından akademisyen ve muhasebe meslek mensuplarının görüsleri arasında fark vardır,

H2: Muhasebe eğitiminde yeteneğin önemi açısından akademisyen ve muhasebe meslek mensuplarının görüşleri arasında fark vardır ve

H3: Muhasebe eğitiminde tutumun önemi açısından akademisyen ve muhasebe meslek mensuplarının görüşleri arasında fark vardır hipotezleri kabul edilmiştir.

\subsubsection{Muhasebe Eğitiminde Bilginin Alt Boyutlarının Önem Düzeylerinin Meslek Değişkenine Yönelik Bulguları}

Akademisyenler ile muhasebe meslek mensuplarının muhasebe eğitiminde bilginin alt boyutlarının önemine ilişkin görüşlerinde fark olup olmadığı Tablo 8'de yer almaktadır.

Tablo 8: Meslek Değişkenine Göre Bilginin Alt Boyutlarının Önem Düzeylerinde Anlamlı Bir Farkın Olup Olmadığını Belirlemek İçin Yapılan Bağımsız Grup T Testi Sonuçları

\begin{tabular}{|c|c|c|c|c|c|c|}
\hline Boyut & Grup & $N$ & $X$ & $S S$ & $F$ & $\boldsymbol{P}$ \\
\hline \multirow{2}{*}{$\begin{array}{l}\text { Muhasebe, Finans ve İliş̧kili } \\
\text { Diğer Kavramlar }\end{array}$} & Akademisyen & 68 & 3,81 & 0,98 & \multirow[t]{2}{*}{3,392} & \multirow{2}{*}{,735* } \\
\hline & $\begin{array}{l}\text { Muhasebe Meslek } \\
\text { Mensubu }\end{array}$ & 89 & 3,75 & 1,24 & & \\
\hline \multirow{2}{*}{$\begin{array}{l}\text { İş Aktiviteleri ve İşletme } \\
\text { Yönetimi }\end{array}$} & Akademisyen & 68 & 3,48 & 1,03 & \multirow[t]{2}{*}{0,162} & \multirow[t]{2}{*}{, $000 *$} \\
\hline & $\begin{array}{l}\text { Muhasebe Meslek } \\
\text { Mensubu }\end{array}$ & 89 & 4,19 & 1,10 & & \\
\hline \multirow[t]{2}{*}{ Bilgi Teknolojileri } & Akademisyen & 68 & 3,02 & 1,29 & 0,434 &, $002 *$ \\
\hline & $\begin{array}{l}\text { Muhasebe Meslek } \\
\text { Mensubu }\end{array}$ & 89 & 3,63 & 1,15 & & \\
\hline
\end{tabular}

* $\mathbf{p}<0,05$ 
Tablodaki değerlere bakıldığında muhasebe eğitiminde bilginin alt boyutlarını oluşturan iş aktiviteleri ve işletme yönetimi ile bilgi teknolojileri konularının önem derecesi noktasında akademisyen ve muhasebe meslek mensuplarının farklı düşünceye sahip olduğu, buna karşın muhasebe, finans ve ilişkili diğer kavramların önem düzeyi noktasında ise iki grup arasında görüş farkının olmadığı ifade edilebilmektedir.

\subsubsection{Muhasebe Eğitiminde Yeteneğin Alt Boyutlarının Önem Düzeylerinin Meslek Değişkenine Yönelik Bulguları}

Akademisyenler ile muhasebe meslek mensuplarının muhasebe eğitiminde yeteneğin alt boyutlarının önemine ilişkin görüşlerinde fark olup olmadığı Tablo 9' da yer almaktadır.

Tablo 9: Meslek Değişkenine Göre Yeteneğin Alt Boyutlarının Önem Düzeylerinde Anlamlı Bir Farkın Olup Olmadığını Belirlemek İçin Yapılan Bağımsız Grup T Testi Sonuçları

\begin{tabular}{|c|c|c|c|c|c|c|}
\hline Boyut & Grup & $N$ & $X$ & $S S$ & $F$ & $P$ \\
\hline \multirow[t]{2}{*}{ Entelektüel Yetenek } & Akademisyen & 68 & 2,96 & 1,58 & \multirow[t]{2}{*}{21,831} & \multirow[t]{2}{*}{, 001} \\
\hline & $\begin{array}{l}\text { Muhasebe Meslek } \\
\text { Mensubu }\end{array}$ & 89 & 3,76 & 1,25 & & \\
\hline \multirow{2}{*}{$\begin{array}{l}\text { Teknik ve İşlevsel } \\
\text { Yetenek }\end{array}$} & Akademisyen & 68 & 3,10 & 1,39 & \multirow[t]{2}{*}{14,597} & \multirow[t]{2}{*}{, 002} \\
\hline & $\begin{array}{l}\text { Muhasebe Meslek } \\
\text { Mensubu }\end{array}$ & 89 & 3,78 & 1,18 & & \\
\hline \multirow[t]{2}{*}{ Kişisel Yetenek } & Akademisyen & 68 & 3,00 & 1,31 & \multirow[t]{2}{*}{8,277} & \multirow[t]{2}{*}{, $000^{\prime}$} \\
\hline & $\begin{array}{l}\text { Muhasebe Meslek } \\
\text { Mensubu }\end{array}$ & 89 & 3,79 & 1,15 & & \\
\hline \multirow{2}{*}{$\begin{array}{l}\text { Kişilerarası } \\
\text { Yetenekleri }\end{array}$} & Akademisyen & 68 & 3,07 & 1,21 & \multirow[t]{2}{*}{8,356} & \multirow[t]{2}{*}{, $002 *$} \\
\hline & $\begin{array}{l}\text { Muhasebe Meslek } \\
\text { Mensubu }\end{array}$ & 89 & 3,64 & 1,03 & & \\
\hline \multirow{2}{*}{$\begin{array}{l}\text { Organizasyonel } \\
\text { İsletme } \\
\text { Yeteneği }\end{array}$} & Akademisyen & 68 & 3,16 & 1,07 & \multirow[t]{2}{*}{3,558} & \multirow[t]{2}{*}{, $001 *$} \\
\hline & $\begin{array}{l}\text { Muhasebe Meslek } \\
\text { Mensubu }\end{array}$ & 89 & 3,73 & 0,94 & & \\
\hline
\end{tabular}

$* \mathbf{p}<0,05$

Tablodaki değerlere bakıldığında yeteneğin alt boyutlarını oluşturan entelektüel yetenek, teknik ve işlevsel yetenek, kişisel yetenek, kişilerarası iletişim yetenekleri ve organizasyonel ve işletme yönetimi yeteneği konularında akademisyen ve muhasebe meslek mensuplarının görüşlerin arasında farkın olduğu söylenebilmektedir $(\mathrm{p}<0,05)$.

\subsubsection{Muhasebe Eğitiminde Tutumun Öneminin Karşılaştırılması}

Akademisyenler ile muhasebe meslek mensuplarının muhasebe eğitiminde tutumun alt boyutlarının önemine ilişkin görüşlerinde fark olup olmadığı Tablo 10'da yer almaktadır. 
Tablo 10: Meslek Değișkenine Göre Tutumun Alt Boyutlarının Önem Düzeylerinde Anlamı Bir Farkın Olup Olmadığını Belirlemek İçin Yapılan Bağımsız Grup T Testi Sonuçları

\begin{tabular}{|c|c|c|c|c|c|c|}
\hline Boyut & Grup & $N$ & $X$ & $S S$ & $F$ & $P$ \\
\hline \multirow[b]{2}{*}{ Genel İlkeler } & Akademisyen & 68 & 2,96 & 1,57 & \multirow[t]{2}{*}{25,848} & \multirow[t]{2}{*}{, $001 *$} \\
\hline & $\begin{array}{l}\text { Muhasebe Meslek } \\
\text { Mensubu }\end{array}$ & 89 & 3,85 & 1,22 & & \\
\hline \multirow{2}{*}{ Ayrıntılı İlkeler } & Akademisyen & 68 & 3,10 & 1,51 & \multirow[t]{2}{*}{29,468} & \multirow[t]{2}{*}{, $002 *$} \\
\hline & $\begin{array}{l}\text { Muhasebe Meslek } \\
\text { Mensubu }\end{array}$ & 89 & 3,95 & 1,11 & & \\
\hline
\end{tabular}

$* \mathbf{p}<0,05$

Tablodaki değerlere bakıldığında tutumun alt boyutlarını oluşturan genel ve ayrıntılı ilke konularında akademisyen ve muhasebe meslek mensuplarının görüşlerin arasında farkın olduğu söylenebilmektedir $(\mathrm{p}<0,05)$.

\section{TARTIŞMA, SONUÇ VE ÖNERILLER}

Günümüz koşullarında etkin bir muhasebe eğitimi için geleneksel eğitim materyallerinin yanı sıra pratik uygulamaların da yer alması gereği bilinmektedir. Üniversitelerin muhasebe bölümlerinden mezun olan öğrenciler, iş hayatlarında uygulamalarla karşılaşmakta ve eğitim müfredatlarındaki uygulama eksikliklerinden dolayı sıkıntı yaşamaktadırlar. $\mathrm{Bu}$ sebeple üniversitelerin muhasebe müfredatları, geleceğin meslek mensubu olan öğrencilerin söz konusu sıkıntılarını giderici niteliğe sahip olmalıdır. $\mathrm{Bu}$ nedenle gerek üniversite müfredatlarında gerekse iş yaşamında bilgi teknolojilerinden faydalanılarak yeni uygulamaların kullanılması muhasebe eğitiminin kalitesini artıracaktır. $\mathrm{Bu}$ doğrultuda çalışmanın amacı uluslararası muhasebe eğitimi standartları çerçevesinde muhasebe eğitiminde akademisyen ve meslek mensuplarının görüşlerini belirlemeye yöneliktir. Çalışmada öngörülen üç tane hipotez yer almaktadır.

H1 hipotezi, $\mathrm{p}=0,031$ değeri ile kabul edilmiştir. Bunun anlamı muhasebe eğitiminde bilginin önemi açısından akademisyen ve muhasebe meslek mensuplarının görüşleri arasında farklılık bulunmaktadır. Akademisyenler için finansal muhasebe, finansal raporlama, vergilendirme, iş ve ticari hukuk, denetim ve etik gibi temel konular muhasebe eğitiminde oldukça önem arz etmektedir. Muhasebe meslek mensupları için de yukarıda bahsedilen konular bilgi açısından önemli sayılacak düzeyde olsa da $(4,06)$ akademisyenlerin görüşleriyle kıyaslandığında düşüktür $(3,58)$. İş aktiviteleri ve işletme yönetimiyle ilgili bilgiler değerlendirildiğinde ise her muhasebe meslek mensuplarına göre önemli iken akademisyenlerin bu bilginin önemine verdikleri yanıtların ortalaması düşüktür. Uluslararası ticaret ve küreselleşme, pazarlama, organizasyonel davranış, iş çevresiyle ilgili bilgilerin muhasebe eğitiminde çok fazla öneme sahip olmadığı çalışma sonuçlarına göre ifade edilmektedir. Bilgi teknolojilerine yönelik yapılan değerlendirme sonuçlarına bakıldığında gerek akademisyen gerekse meslek mensuplarına göre orta düzeyde öneme sahip olduğu söylenebilmektedir. Bilgi teknolojileri ve kullanıcılarına ilişkin bilgiler önemli iken bilgi teknolojilerinin yönetici ve tasarımcılığına ilişkin bilgilerin muhasebe eğitiminde önemli olmadığı her iki grup için de belirtilmiştir. 
$\mathrm{H} 2$ hipotezi, $\mathrm{p}=0,010$ değeri ile kabul edilmiştir. Bunun anlamı muhasebe eğitiminde bilginin önemi açısından akademisyen ve muhasebe meslek mensuplarının görüşleri arasında farklılık bulunmaktadır. Akademisyenlerin görüşleriyle kıyaslama yapıldığında muhasebe meslek mensuplarına göre yeteneğin muhasebe eğitimindeki önemi daha yüksektir. Özellikle bir kişiden yazılı ve elektronik ortamlardan bilgi alabilme ve anlayabilme, araştırma, mantıksal düşünme, sebep sonuç analizi yapabilme ve olaylara eleştirel gözle bakabilme yeteneği muhasebe meslek mensuplarına göre çok önemlidir. Ayrıca düşünce ve mesleki bilgelik ve liderlik yeteneği kazanma, görevleri organize etme, stratejik planlama, insan kaynakları yönetimi, gibi konular da muhasebe meslek mensupları açısından önemlidir.

H3 hipotezi, $p=0,003$ değeri ile kabul edilmiştir. Bunun anlamı muhasebe eğitiminde yeteneğin önemi açısından akademisyen ve muhasebe meslek mensuplarının görüşleri arasında farklılık bulunmaktadır. Akademisyenlerin görüşleriyle kıyaslama yapıldığında muhasebe meslek mensuplarına göre yeteneğin muhasebe eğitimindeki önemi daha yüksektir $(3,76)$. Muhasebe meslek mensuplarına göre kamu yararı ve sosyal sorumluluk, duyarlı olma, kendini geliştirme, sürekli öğrenme, güvenilir, sorumlu, zamanında davranma özellikleri muhasebe eğitimi için önemli sayılırken $(3,69)$, bu boyut akademisyenlerin cevaplarının ortalaması oldukça düşüktür $(2,96)$. Ayrıca muhasebe meslek mensuplarına göre iş aktivitelerinde etik davranış gösterme, teknik standartlara uyumlu davranış sergileme gibi ilkelerde muhasebe eğitiminde mutlaka yer almalıdır.

Çalışma genel olarak değerlendirildiğinde akademisyenlerin ve muhasebe meslek mensuplarının muhasebe eğitimiyle ilgili farklı düşüncelere sahip olduğu söylenebilmektedir. $\mathrm{Bu}$ farklılığın nedeni olarak akademisyenlerin daha çok muhasebenin teorik alt yapısını oluşturmak istemelerinden dolayı, temel kavramları müfredata dâhil etmek istemeleri muhasebe meslek mensuplarının ise iş yaşamında teorik bilginin yanı sıra olağanüstü durumlarda hızlı kararların alınabilmesi için uygulamalara ve pratik bilgilere de ihtiyaç duyulduğu ifade edilebilmektedir.

$\mathrm{Bu}$ çalışmanın sonuçlarının gerek akademisyenlere gerekse muhasebe meslek mensuplarına birtakım öneriler sunması açısından katkı sağlayacağı düşünülmektedir. Ayrıca çalışmanın sonuçları işletme ihtiyaçları ile oluşturulan muhasebe müfredatların da farklılığın olduğunu göstermektedir. $\mathrm{Bu}$ çalışma muhasebe müfredatları oluşturulurken bilgiye verilen önem kadar yetenek ve tutumunda dikkate alınması gerekliliği noktasında akademisyenlere öneri niteliği taşımaktadır. Sugahara vd. (2010), Çürük ve Doğan (2002) ve Çubukçu (2012)'ya göre de muhasebe eğitiminde bilginin yanı sıra yetenek ve tutuma da aynı oranda yer verilmesi gerekmektedir.

Sonuç olarak bu çalışma, muhasebe eğitiminde bilgi, yetenek ve tutumun önemini belirlemeye yönelik akademisyen ve muhasebe meslek mensuplarının görüşlerini değerlendirmeyi içermektedir. Bununla birlikte gelecek çalışmalarda muhasebe eğitimine yönelik katılımcılarla röportaj yapılarak müfredat eksiklikleri belirlenebilir. Ayrıca bu çalışmada uluslararası muhasebe standartları sadece boyutların belirlenebilmesi için kullanılmış olup gelecek çalışmalarda bu standartların her birinin muhasebe müfredatında uygulanabilirliğinin ölçülmesi de öneri niteliği taşımaktadır. 


\section{KAYNAKÇA}

Arıkan, R. (2004). Araştırma teknikleri ve rapor hazırlama. Ankara: Asil Yayın

Can, A.,V. ve Demirci, Ş., D. (2016). Uluslararası muhasebe eğitimi standardı 2 muhasebe eğitim programlarının içeriğine uyum: Sakarya üniversitesi örneği, Uluslararası yönetim İktisat ve İşletme Dergisi ICAFR 16 Özel Saylsı, 319-338.

Crawford, L., Helliar, C., Monk, E. ve Veneziani, M. (2011). International accounting education standards board: organizational legitimacy within the field of Professional accountancy education. Accounting Forum, 38, 67-89.

Çelik, O. ve Ecer, A. (2009). Efficiency in accounting education: evidence from Turkish Universities. Critical Perspectives on Accounting, 20, 614-634.

Çubukçu, S. (2012). Uluslararası muhasebe eğitimi standartları komitesi düzenlemeleri çerçevesinde etik eğitimine ilişkin durum analizi, Anadolu Üniversitesi Sosyal Bilimler Enstitüsü Dergisi, 12(1), 103-116.

Çürük, T. ve Doğan, Z. (2002). Muhasebe ders ve içeriklerinin verilme düzeyleri konusunda işletmelerin üniversitelerden taleplerinin tespitine ilişkin bir araştırma. Dokuz Eylül Üniversitesi İ.̇.B.F. Dergisi, 17 (1), 107-126.

Eastman, J. ve Hazera, A. (2009). An examination of accounting education in Mexico and the United States. University of Rhode Island, 1-23.

Frijat, S. ve Shbeilat, M. K. (2016). Jordanian Universities and their role in the trend towards the development of technical competence for accounting learning outcomes in line with IES, Acounting and Finance Research, 5(2), 20-31.

Gökten Okan, P. ve Gökten, S. (2016). Uluslararası eğitim standartlarına genel bakış: geçerliliğinin Türkiye açısından değerlendirilmesi, Gazi Üniversitesi Sosyal Bilimler Dergisi, 3(6), 49-66.

International Federation of Accountants, www.ifac.org. Erişim Tarihi: 15.08.2017.

IFAC Education Committee (2003), Introduction to International Education Standarts for Professional Accountants, Exposure Draft.

Kostadinovski, A., Dimitrova,, J. Ve Georgieva, Svrtinov, V. (2013). International education standards for professional accountants. Jubilee International Scientific Conference, 2. 222-227.

Kutluk, F.,A., Dönmez, A, Utku Demirel B. ve Erdoğan, M. (2012). Expection of accounting professionals from accounting education: An Antalya research, Social and Behavioral Sciences, 62, 418-423.

Moehrle, S., Anderson, K., Ayres, F., Bolt-Lee, C., Debreceny, R., Dugan, M., Hogan, C., Maher, M. and Plummer, E. (2009). The impact of academic accounting research on professional practice: an analysis by the AAA Research Impact Task Force, Accounting Horizons, 23(4), 411.

Montano, J.,L.,A., Gonzalez, L.,M.,G., Hassall, T., Joyce, J., Germanou, E. ve Asonitou, S. (2010). The approaches to learning of European accounting students. EuroMed Journal of Business, 5 (3), 345-362.

Öztürk, E. ve Fındık, H. (2016). Türkiye'deki muhasebe eğitiminin uluslararası muhasebe standartları ile uyumlaştırılması sürecinde karşılaşılan adaptasyon problemlerinin muhasebe alt kültür değerleri çerçevesinde tartış1ması, Muhasebe ve Vergi Uygulamaları Dergisi, 9(3), 241-256.

Pratama, A. (2015). Bridging the gap between academicians and practitioners on accountant competencies: An analysis of international education standards (IES) implementation on Indonesia's accounting, Social and Behavioral Sciences, 211, 19-26.

Saville, H. (2007) International Education Standards for Professional Accountants (IESs), Accounting Education, 16 (1), 107-113.

Stivers, B., P., Onifade, E., Reynolds, R. ve Alli, K. (2011). Introductory accounting for business majors: Revisited. Academy of Educational Leadership Journal. 15 (Özel sayı), 31-47.

Sugahara, S., Suzuki, K. ve Boland, G. (2010). Students' majör choice in accounting and its effect on their self-effiacy towards generic skills: an Australian study. Asian Review of Accounting. 18 (2), 131-147.

Tabachnick, B,.G. ve Fidell, L., S. (2013) Using Multivariate Statistics (6th Edition), Pearson: Boston.

The International Accounting Education Standards Board (2017), www.iaesb.org. Erişim Tarihi: 15.08.2017.

Uyar, S. (2008). Uluslararası muhasebe eğitimi standartları (IES) ve Akdeniz Üniversitesi’nde muhasebe eğitimi, MÖDAV, 1, 79-107. 
Watty, K. (2005). Quality in accounting education: What say the academics?, Quality Assurance in Education, 13(2), $120-131$.

Wilkin, C.,L. ve Collier P., A. (2009). A problem-based approach to accounting education: A pragmatic appraisal of a technologically enabled solution. International Journal of Education and Development using Information and Communication Technology, 5 (2), 49-67.

Zaif, F. Ve Ayanoğlu, Y. (2007). Muhasebe eğitiminde kalitenin arttırılmasında ders programlarının önemi: Türkiye'de bir inceleme, Gazi Üniversitesi İktisadi ve İdari Bilimler Fakültesi Dergisi, 9(1), 115-136. 
Optimum Journal of Economics and Management Sciences, Vo1. 5, No. 2- http://dergipark.gov.trloptimum

Tosunoğlu, Cengiz and Anadolu - Examination of Accounting Education within the scope of International Accounting

Education Standards in terms of Academics and Professional Accountants in Turkey 